\title{
Serum sclerostin level and its relation to subclinical atherosclerosis in the polycystic ovary syndrome phenotypes: A prospective controlled study
}

\section{Serum sclerostin seviyesinin polikistik over sendromu} fenotiplerinde subklinik ateroskleroz ile ilişkisi: Prospektif kontrollü çalışma

\author{
(1) Feyza Nur İncesu Çintesun ${ }^{1}$, (1) Ümmügülsüm $\mathrm{Can}^{2}$, (1) Ersin Çintesun ${ }^{3}$, (1) Ayşegül Altunkeser ${ }^{4}$, \\ (D) Aybike Kaya ${ }^{3}$, (D) Oğuzhan Günenç ${ }^{1}$ \\ ${ }^{1}$ University of Health Sciences Turkey, Konya City Hospital, Clinic of Obstetrics and Gynecology, Konya, Turkey \\ ${ }^{2}$ University of Health Sciences Turkey, Konya City Hospital, Clinic of Biochemistry, Konya, Turkey \\ 3 Selçuk University Faculty of Medicine, Department of Obstetrics and Gynecology, Konya, Turkey \\ ${ }^{4}$ University of Health Sciences Turkey, Konya City Hospital, Clinic of Radiology, Konya, Turkey
}

\begin{abstract}
Objective: We aim to study the relationship between atherosclerosis and serum sclerostin levels in different phenotypes of polycystic ovary syndrome (PCOS).

Materials and Methods: A total of 134 women with PCOS and 33 age-matched controls participated in this study. Women with PCOS were further divided into subgroups based on their PCOS phenotypes: phenotype A $(n=35)$, phenotype B $(n=33)$, phenotype C $(n=31)$, and phenotype D ( $n=35)$. Metabolic parameters, hormonal parameters, carotid intima-media thickness (CIMT), and sclerostin levels were compared among the PCOS phenotypes.

Results: Statistically significant differences occurred among groups regarding follicle-stimulating hormone, luteinizing hormone, estradiol, total cholesterol, low-density lipoprotein, Ferriman-Gallwey score, total testosterone, and free androgen index. The mean CIMT was statistically higher in all PCOS phenotypes than in controls. In subgroup comparison, phenotypes A and B had a higher body mass index (BMI) adjusted CIMT than other phenotypes, respectively $(\mathrm{p}=0.005)$. Serum sclerostin levels were higher in PCOS patients than in controls. A concentration of $\geq 6.297 \mathrm{ng} / \mathrm{mL}$ showed a sensitivity of $56 \%$ and a specificity of $69.7 \%$ to predict PCOS. The BMI-adjusted sclerostin level was significantly higher in phenotype C $(20.3 \pm 0.7 \mathrm{ng} / \mathrm{mL})$ than in other phenotypes. Conclusion: Patients with phenotypes A and B seem to have an increased risk for atherosclerosis. Although sclerostin was higher in PCOS patients, we could not demonstrate the relation between sclerostin and atherosclerosis in different PCOS phenotypes.
\end{abstract}

Keywords: Atherosclerosis, carotid intima-media thickness, polycystic ovary syndrome, sclerostin

$\ddot{\mathrm{O} z}$

Amaç: Bu çalışmada amacımız polikistik over sendromu (PKOS) fenotiplerinde serum sclerostin seviyelerini belirlemek ve ateroskleroz ile ilişkisini araștırmaktır.

Gereç ve Yöntemler: Yüz otuz dört PKOS tanılı hasta ve 33 kontrol hastası çalışmaya dahil edildi. PKOS hastaları fenotiplerine göre 4 alt gruba ayrıldı; fenotip A ( $n=35)$, fenotip B ( $n=33)$, fenotip C $(n=31)$ ve fenotip D $(n=35)$. PKOS fenotiplerinde metabolik, hormonal değişkenler ile karotis intima media kalınlığı (KIMK) ve sclerostin seviyeleri karşılaştırıldı.

Bulgular: Gruplar arasında folikül stimülan hormon, luteinizan hormon, estradiol, total kolesterol, düşük yoğunluklu lipoprotein, Ferriman-Gallwey skoru, total testesteron ve serbest androjen indeksinde istatistiksel olarak farklılıklar tespit edildi. Ortalama KIMK değeri tüm PKOS fenotiplerinde kontrollere göre istatistiksel olarak yüksek bulundu. Alt grup analizinde sırasıyla fenotip A ve B hastalarında vücut kitle indeksi (VKI) düzeltilmiş KIMK değeri diğer gruplara göre yüksek ölçüldü $(\mathrm{p}=0,005)$. Serum sclerostin seviyeleri PKOS hastalarında kontrollere göre yüksek tespit edildi. Sclerostinin 6,297 ng/mL ve üzeri

PRECIS: PCOS patients with phenotype A and B seem to have increased risk for atherosclerosis. Although sclerostin was found higher in PCOS patients than controls, a relation couldn't be demonstrated between sclerostin and atherosclerosis in PCOS patients.

Address for Correspondence/Yazışma Adresi: Asst. Prof. Feyza Nur İncesu Çintesun,

University of Health Sciences Turkey, Konya City Hospital, Clinic of Obstetrics and Gynecology, Konya, Turkey

Phone: +90 5052341235 E-mail: feyzanurincesu@gmail.com ORCID ID: orcid.org/0000-0003-2131-962X

Received/Geliș Tarihi: 10.05.2021 Accepted/Kabul Tarihi: 27.06.2021

${ }^{\oplus}$ Copyright 2021 by Turkish Society of Obstetrics and Gynecology

Turkish Journal of Obstetrics and Gynecology published by Galenos Publishing House 
değerlerinde PKOS hastalığını \%56 sensitivite ve \%69,7 spesifite ile tahmin edebildiği gösterildi. VKİ düzeltilmiş sclerostin seviyeleri fenotip C hastalarında diğer fenotiplere klyasla istatistiksel olarak yüksek bulundu $(20,3 \pm 0,7 \mathrm{ng} / \mathrm{mL})$.

Sonuç: Fenotip A ve B’ye sahip PKOS hastaları ateroskleroz için artmış riske sahip görünmektedirler. Sclerostin seviyeleri PKOS hastalarında genel olarak yüksek bulunsa da, PKOS fenotiplerinde serum sclerostin ile subklinik ateroskleroz ilişkisi net olarak tanımlanamamıştır.

Anahtar Kelimeler: Aterosklerozis, karotis intima media kalınlığı, sclerostin, polikistik over sendromu

\section{Introduction}

Polycystic ovary syndrome (PCOS) is recognized as one of the most common endocrine/metabolic disorders affecting women worldwide. Its prevalence was reported as $10 \%$, according to the Rotterdam criteria $^{(1)}$. These criteria define PCOS for those with at least two of the following three conditions: oligoanovulation, clinical/biochemical hyperandrogenism, and polycystic ovary (PCO) appearance on ultrasonography ${ }^{(2)}$. According to three diagnostic Rotterdam criteria, PCOS is divided into four phenotypes because of the heterogeneity of the signs and symptoms. The spectrum extends from women showing the classical features to those who may not even have features of hyperandrogenism: phenotype A (hyperandrogenism + PCO + oligo-anovulation), phenotype B (hyperandrogenism + oligo-anovulation), phenotype C (hyperandrogenism + PCO), and phenotype $\mathrm{D}$ (oligo-anovulation $+\mathrm{PCO})^{(3)}$. In a review, most PCOS patients $(60 \%)$ were categorized into phenotype $\mathrm{A}^{(4)}$. Phenotype A is known as full, phenotype B is known as classical, phenotype $\mathrm{C}$ is known as ovulatory, and phenotype $\mathrm{D}$ is known as non-hyperandrogenic $\mathrm{PCOS}^{(3)}$. In women with full and classical phenotypes of PCOS (phenotypes A and B), higher levels of luteinizing hormone (LH)/follicle-stimulating hormone (FSH) ratios, higher risk of insulin resistance (IR) ${ }^{(5)}$, and metabolic disturbances ${ }^{(6)}$, and more severe forms of atherogenic dyslipidemia ${ }^{(7)}$ existed than did ovulatory and nonhyperandrogenic PCOS phenotypes. Studies show the association between subclinical atherosclerosis, endothelial dysfunction, and $\operatorname{PCOS}{ }^{(8,9)}$. Studying the clinical, hormonal, and metabolic parameters of these phenotypes can help to specify the riskiest phenotypes.

Sclerostin is a cysteine-rich glycoprotein, which is predominately secreted by osteocytes ${ }^{(10)}$. It retards the Wingless-type Mouse mammary tumor virus integration site (Wnt) pathway via binding its LRP5/6 coreceptors $^{(10)}$. LRP5/6 acts to regulate glucose and lipid metabolism. Mutations in LRP5/6 are responsible for hypertension, type 2 diabetes, high low-density lipoprotein (LDL) cholesterol and triglycerides (TG), and early coronary artery disease ${ }^{(11)}$. Defective Wnt and LRP5/6 signaling could cause atherosclerosis ${ }^{(12)}$. Also, sclerostin is associated with subclinical atherosclerosis in type 2 diabetes mellitus and chronic kidney disease patients ${ }^{(13,14)}$.

In the literature, there is no data regarding serum sclerostin levels in PCOS patients. We aim to determine whether there is an alteration in sclerostin levels and any link between sclerostin levels and subclinical atherosclerosis in women with PCOS.

\section{Materials and Methods}

\section{Study Design and Patient Selection}

This prospective case-control study was conducted from June 2019 to July 2020 at a tertiary hospital with approval from the local institutional review board (reg. no. 2019/184). All patients gave written informed consent after they were informed about the study protocol and aim. The study was conducted in accordance with the Helsinki Declaration Principles.

All the women presented with one or two or all of the following complaints: oligomenorrhea, hirsutism, and infertility, and were systematically evaluated in our outpatient clinic. During the systematic evaluation, all the participants underwent a physical examination and sonographic evaluation and were screened for hormonal abnormalities. A total of 134 women with PCOS and 33 age-matched controls participated in this study. The diagnosis of PCOS was made according to the Rotterdam criteria $^{(2)}$ in the presence of at least two of the following: oligomenorrhea and/or anovulation, biochemical and/or clinical hyperandrogenism, and ultrasound appearance of PCO. Other etiologies, such as congenital adrenal hyperplasia, virilizing tumor, Cushing syndrome, thyroid dysfunction, prolactinoma, diabetes, hypertension, and other cardiovascular diseases, were considered exclusion criteria. Patients who had taken any medication that could affect gonadotropin, lipid, and carbohydrate metabolism during the previous three months were excluded from the study. No subject smoked or consumed alcohol. Women with PCOS were further divided into subgroups based on the PCOS phenotypes: phenotype A, phenotype B, phenotype $\mathrm{C}$, and phenotype $\mathrm{D}$ (as mentioned above). As controls, 33 age-matched women who had regular menses and had no clinical or biochemical hyperandrogenism or PCO were eligible. Oligomenorrhea was diagnosed in patients with cycles longer than 35-day intervals or with fewer than eight cycles of menstruation during the past 12 months, and amenorrhea was determined in the absence of menstruation for three consecutive months. Clinical hyperandrogenism was defined as the presence of hirsutism and/or acne and/or alopecia. Hirsutism was evaluated according to the modified Ferriman-Gallwey score, and patients with a total score $\geq 8$ were considered hirsute ${ }^{(15)}$. Biochemical hyperandrogenism was defined as total testosterone greater than $80 \mathrm{ng} / \mathrm{dL}$. PCO was defined as the presence of 12 or more ovarian cysts with 2-9 $\mathrm{mm}$ diameter per ovary and/or ovarian volume (OV) $\geq 10 \mathrm{~cm}^{3(2)}$.

The initial physical examination included weight, height, waist and hip circumferences to calculate the waist-hip ratio (WHR) 
and BMI. Waist and hip circumferences were measured as described by Dilbaz et al. ${ }^{(16)}$. BMI was calculated as the ratio of weight divided by height squared $\left(\mathrm{kg} / \mathrm{m}^{2}\right)$. The patients with a BMI value of $\geq 18 \mathrm{~kg} / \mathrm{m}^{2}$ and $\leq 30 \mathrm{~kg} / \mathrm{m}^{2}$ were enrolled in the study. The BMI, WHR, and hirsutism scores were assessed by the same physician (FNiÇ) for all subjects.

All regularly menstruating women were scanned by ultrasound on cycle days 3-5, whereas oligo/amenorrheic women were scanned between days 3 and 5 after progestin-induced withdrawal of bleeding. Ovarian morphology was evaluated with transvaginal ultrasound (Esaote My Lab Seven, 2018, Italy) by the same physician (FNiÇ). The size and the total number of antral ovarian follicles $2-9 \mathrm{~mm}$ (AFC) were evaluated. OV was measured using a simplified formula for the volume of a prolate ellipsoid: $\mathrm{OV}=0.5 \times$ length $\times$ height $\times$ width $^{(17)}$.

\section{Biochemical Analysis}

All blood samples were taken in the early follicular phase (day $2-5$ of the menstrual cycle) in the morning after an overnight fast. Then, serum samples were stored at $-70{ }^{\circ} \mathrm{C}$ until further analysis. Routine chemistry laboratory investigations included fasting blood glucose, total cholesterol, high-density lipoprotein (HDL), LDL, and TG were measured using the Beckman Synchron AU 5800 (Beckman Coulter, USA), according to standard laboratory techniques. Routine hormonal analysis of LH, FSH, estradiol (E2), thyroid-stimulating hormone, fasting insulin, and total testosterone was done by chemiluminescence methods using ADVIA Centaurl XP immunoassay system (Siemens Diagnostics, Germany). Sex hormone-binding globulin (SHBG) was measured with the YLBIONT SHBG ELISA Kit (Shanghai YL Biotech Co., Ltd) in accordance with the manufacturer's guidelines. SHBG was reported in nanomoles per liter. IR was determined by the homeostasis model assessment (HOMA-IR) index [fasting glucose $(\mathrm{mg} / \mathrm{dL}) \times$ fasting insulin $(\mathrm{mU} / \mathrm{mL}) / 405]$. Free androgen index (FAI) was calculated according to the equation total testosterone (nmol/L) $\times 100 /$ SHBG $(\mathrm{nmol} / \mathrm{L})$. Serum sclerostin was detected with the YLBIONT sclerostin ELISA Kit (Shanghai YL Biotech Co., Ltd) in accordance with the manufacturer's guidelines. Sclerostin measurements are reported in nanograms per milliliter.

\section{Carotid Artery Studies}

Carotid intima-media thickness (CIMT) was determined by the same radiologist (AA) using high-resolution ultrasound (Toshiba Aplio 500, Japan) with a multifrequency linear probe (5-12 MHz) and standardized image settings. The bilateral distal common carotid arteries, $1 \mathrm{~cm}$ proximal to the bifurcation, were imaged during end-diastole, with the patient in a supine position and the neck slightly extended. CIMT was defined as the distance between the leading edges of the lumen-intima interface and the media-adventitia interface of the far wall of the carotid artery; the mean of 6 recordings ( 3 on each side) was calculated. The highest value of the two sides was accepted for each patient. A CIMT higher than $0.9 \mathrm{~mm}$ was accepted as atherosclerosis ${ }^{(13,18)}$.

\section{Statistical Analysis}

Data are presented as mean \pm standard deviation, median (minimum-maximum), wherever appropriate, and analyzed using SPSS software (IBM statistics, version 21). Parameters of PCOS phenotypes and controls were compared using One-Way ANOVA or Kruskal-Wallis analysis. When the p-value from oneway ANOVA or Kruskal-Wallis test statistics was statistically significant for Post-hoc analysis, the Games-Howel or MannWhitney U test was applied. Analysis of covariance (ANCOVA) was used to determine significant differences in CIMT and sclerostin between cases and controls after adjusting for confounders. Age and BMI were used for adjustment. Spearman correlation was used for correlation analysis of variables with CIMT and sclerostin. A receiver operating characteristic (ROC) analysis was also used for cutoff value, specificity, sensitivity, and AUC detection. A p $<0.05$ was considered significant.

\section{Results}

The clinical characteristics and steroid hormone levels of the study population are presented in Table 1. Statistically significant differences were found among PCOS phenotypes and the control group regarding FSH, LH, estradiol, total cholesterol, LDL, Ferriman-Gallwey score, total testosterone, FAI, over volume, and antral follicle count. The BMI significantly differed between groups ( $\mathrm{p}=0.028$ ). FSH was significantly lower, and LH was significantly higher in phenotypes A and D than in controls, whereas E2 was significantly lower in phenotypes B and C than in the control group. Estradiol was higher in phenotype A than in phenotypes B and C in the subgroup analysis. All PCOS patients had higher total cholesterol, LDL, and TG levels than the control group. In the phenotype $C$ group, compared with phenotypes A and B, LDL and total cholesterol levels were significantly lower. In clinical hyperandrogenism evaluation, control patients had statistically lower FGS than phenotypes A, $\mathrm{B}$, and $\mathrm{C}$. In the biochemical hyperandrogenism evaluation, the control group had significantly lower mean total testosterone levels than phenotypes A, B, and C. Phenotype D had lower total testosterone levels than other phenotypes statistically. Therefore, phenotype D was known as the nonhyperandrogenic group. AFC was statistically higher in all PCOS patients but not in controls, and the lowest AFC was found in phenotype $\mathrm{B}$ in the phenotype comparison. The mean CIMT was found statistically higher in phenotypes A and B than in controls. Significant differences in CIMT persisted after adjusting for BMI. CIMT was higher in all PCOS phenotypes than in controls $(\mathrm{p}=0.015)$. In the subgroup analysis, phenotypes A and B had the highest mean CIMT $(0.488 \pm 0.005 \mathrm{~mm}$ and $0.480 \pm 0.003$ $\mathrm{mm}$ ), whereas phenotype $\mathrm{D}$ had the lowest mean CIMT $(0.460 \pm 0.005 \mathrm{~mm})$. Sclerostin levels were detected significantly higher only in phenotype $\mathrm{C}$ than in controls. The BMI-adjusted 
Table 1. Clinical, biochemical, and radiological parameters in the PCOS phenotypes and control group

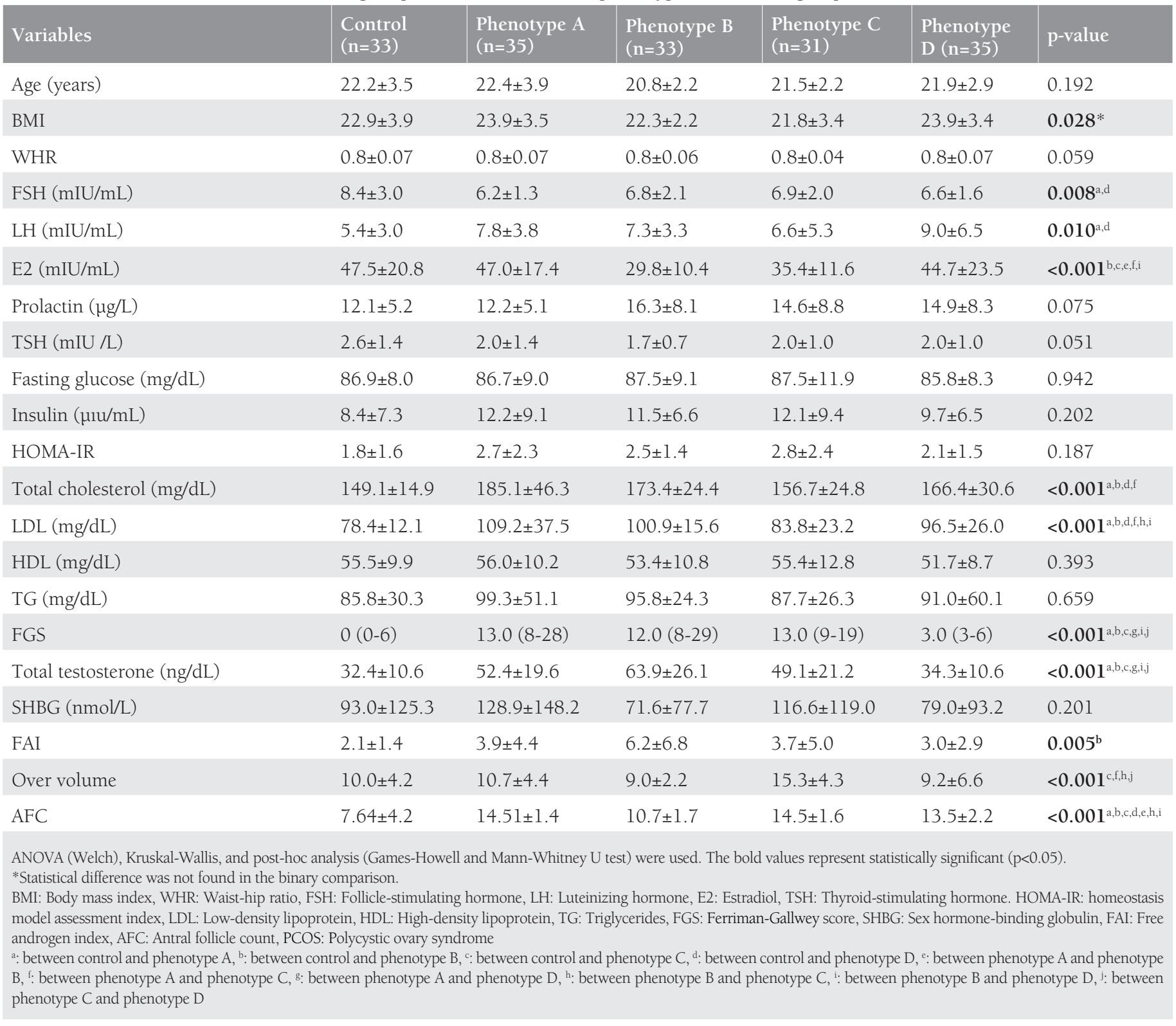

Table 2. CIMT and sclerostin in the PCOS phenotypes and control group

\begin{tabular}{|c|c|c|c|c|c|}
\hline Variables & Phenotype A & Phenotype B & Phenotype C & Phenotype D & Control \\
\hline
\end{tabular}

CIMT (mm)

\begin{tabular}{|c|c|c|c|c|c|c|}
\hline Unadjusted & $0.49 \pm 0.07$ & $0.48 \pm 0.06$ & $0.46 \pm 0.05$ & $0.46 \pm 0.04$ & $0.44 \pm 0.06$ & $0.015^{\mathrm{a}, \mathrm{b}}$ \\
\hline Adjusted $^{1}$ & $0.488 \pm 0.005$ & $0.480 \pm 0.003$ & $0.464 \pm 0.005$ & $0.460 \pm 0.005$ & $0.438 \pm 0.005$ & $0.005^{\mathrm{a}, \mathrm{b}, \mathrm{c}, \mathrm{d}, \mathrm{e}, \mathrm{f}, \mathrm{g}, \mathrm{h}, \mathrm{i}, \mathrm{j}}$ \\
\hline \multicolumn{7}{|c|}{ Sclerostin (ng/mL) } \\
\hline Unadjusted & $13.7 \pm 15.1$ & $13.4 \pm 13.1$ & $20.3 \pm 18.4$ & $17.2 \pm 0.2$ & $8.5 \pm 11.5$ & $0.025^{c}$ \\
\hline Adjusted $^{1}$ & $13.7 \pm 0.7$ & $13.4 \pm 0.4$ & $20.3 \pm 0.7$ & $17.2 \pm 0.7$ & $8.5 \pm 0.8$ & $<0.001^{a, b, c, d, e, f, g, h, j}$ \\
\hline
\end{tabular}

ANOVA (Welch); Kruskal-Wallis and post-hoc analysis (Games-Howell and Mann-Whitney U test) were used. The bold values represent statistically significant (p<0.05). CIMT: Carotid intima-media thickness, PCOS: Polycystic ovary syndrome

${ }^{1}$ Analysis of covariance (ANCOVA), adjusted for BMI, ${ }^{\text {a: }}$ between control and phenotype A, b: between control and phenotype B, $:$ : between control and phenotype C, ${ }^{\mathrm{d}}:$ between control and phenotype $\mathrm{D}$, : between phenotype $\mathrm{A}$ and phenotype $\mathrm{B}$, $:$ between phenotype $\mathrm{A}$ and phenotype $\mathrm{C}, \mathrm{g}:$ between phenotype $\mathrm{A}$ and phenotype $\mathrm{D}$, ${ }^{\mathrm{h}}$ : between phenotype $\mathrm{B}$ and phenotype $\mathrm{C}, \mathrm{i}:$ between phenotype $\mathrm{B}$ and phenotype $\mathrm{D}, \mathrm{j}:$ between phenotype $\mathrm{C}$ and phenotype $\mathrm{D}$ 
sclerostin level $(20.3 \pm 0.7 \mathrm{ng} / \mathrm{mL})$ was significantly higher in phenotype $\mathrm{C}$, whereas phenotypes A and B had the lowest sclerostin values (Table 2). A weak positive correlation was found in the correlation of sclerostin, CIMT, and cardiovascular risk factors, such as BMI, WHR, total cholesterol, LDL, HDL, triglyceride, and HOMA-IR between sclerostin and total cholesterol A weak negative correlation was found between sclerostin and HDL ( $\mathrm{p}=0.029$ and $\mathrm{p}=0.016$, respectively) (Table 3). We compared CIMT and sclerostin levels among PCOS patients with and without biochemical hyperandrogenism. Although the hyperandrogenic group had a higher mean CMIT $(0.48 \pm 0.06 \mathrm{~mm})$ and sclerostin levels $(16.9 \pm 16.4 \mathrm{ng} / \mathrm{mL})$, the two groups were statistically similar $(\mathrm{p}=0.421$ and $\mathrm{p}=0.192$, respectively) (Table 4).

A ROC curve analysis was performed to evaluate the usefulness of sclerostin as a marker for PCOS. It showed an area under the curve of $(0.656, \mathrm{p}=0.006)$ for predicting PCOS. A concentration of $6.297 \mathrm{ng} / \mathrm{mL}$ showed a sensitivity of $56 \%$ and a specificity of $69.7 \%$ to identify an increased risk for PCOS. The diagnostic performance of sclerostin revealed a specific marker rather than a sensitive marker (Table 5, Figure 1).

Table 3. The correlations of cardiovascular risk factors and CIMT and sclerostin in the PCOS phenotypes

\begin{tabular}{|lllll|}
\hline & \multicolumn{2}{c}{ CIMT (mm) } & \multicolumn{2}{c}{ Sclerostin $(\mathrm{ng} / \mathrm{mL})$} \\
\hline BMI & 0.052 & 0.504 & 0.084 & 0.337 \\
WHR & 0.069 & 0.377 & 0.147 & 0.090 \\
\hline $\begin{array}{l}\text { Total } \\
\text { cholesterol }\end{array}$ & 0.013 & 0.866 & 0.169 & 0.029 \\
\hline LDL & 0.004 & 0.963 & 0.139 & 0.072 \\
\hline HDL & -0.043 & 0.580 & -0.186 & 0.016 \\
\hline Triglyceride & 0.022 & 0.779 & -0.063 & 0.418 \\
\hline HOMA-IR & 0.016 & 0.841 & -0.141 & 0.104 \\
\hline Sclerostin & 0.079 & 0.310 & - &.
\end{tabular}

CIMT: Carotid intima-media thickness, BMI: Body mass index, WHR: Waist-hip ratio, LDL: Low-density lipoprotein, HDL: High-density lipoprotein, HOMA-IR: Homeostasis model assessment index.

Spearman correlation was used. The bold values represent statistically significant $(\mathrm{p}<0.05)$

Table 4. The comparison of CIMT and sclerostin in PCOS patients with and without hyperandrogenism

\begin{tabular}{|l|l|l|l|} 
& $\begin{array}{l}\text { Hyperandrogenic } \\
\text { PCOS group } \\
\mathrm{n}=99\end{array}$ & $\begin{array}{l}\text { Normoadrogenic } \\
\text { PCOS group } \\
\mathrm{n}=35\end{array}$ & p-value \\
\hline CIMT (mm) & $0.48 \pm 0.06$ & $0.46 \pm 0.04$ & 0.421 \\
\hline $\begin{array}{l}\text { Sclerostin } \\
(\mathrm{ng} / \mathrm{mL})\end{array}$ & $16.9 \pm 16.4$ & $13.7 \pm 15.1$ & 0.192 \\
\hline
\end{tabular}

CIMT: Carotid intima-media thickness

Student t-test was used
Table 5. Best cutoff value, specificity, sensitivity, and AUC of sclerostin

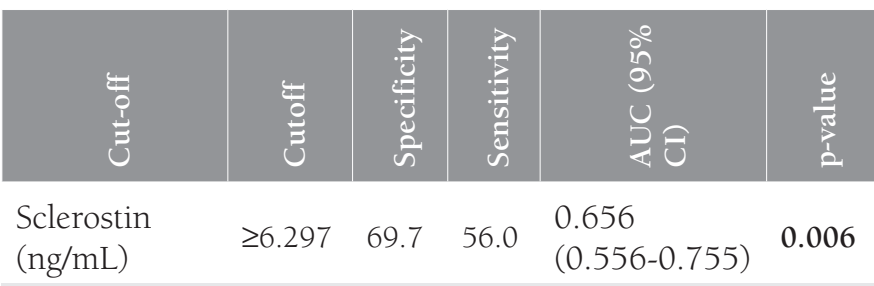

AUC: area under the curve, CI: confidence interval

The bold values represent statistically significant $(\mathrm{p}<0.05)$

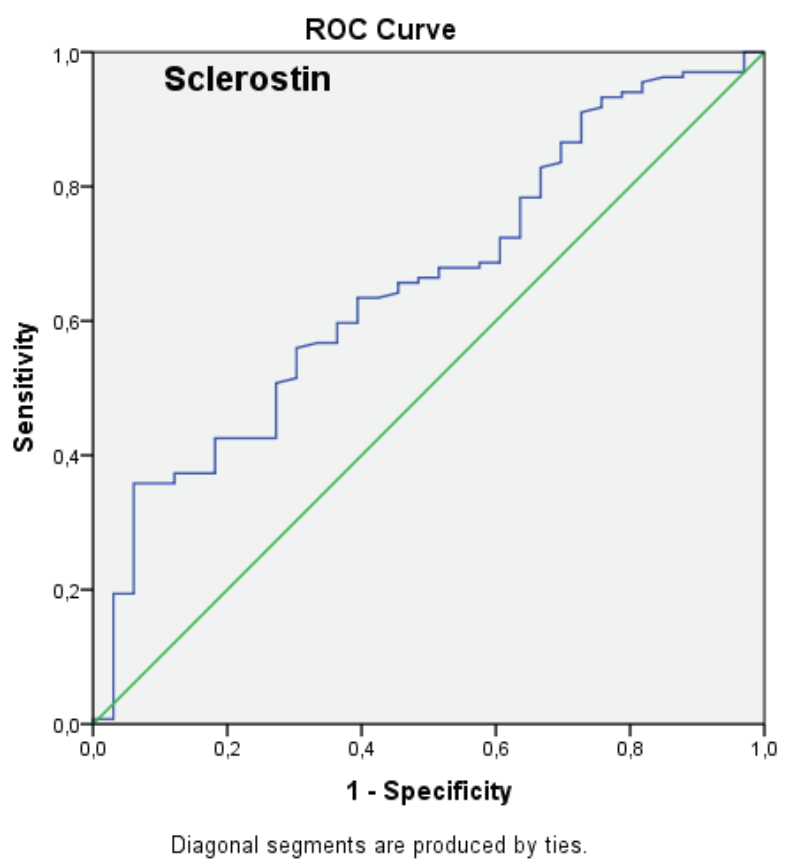

Figure 1. ROC curve for sclerostin $(\mathrm{ng} / \mathrm{mL})$ to the prediction of PCOS

ROC: Receiver operating characteristic, PCOS: Polycystic ovary syndrome

\section{Discussion}

This study demonstrated higher levels of sclerostin and CMIT in PCOS patients than those in healthy subjects. We also found that full and classic PCOS patients had the highest BMIadjusted CMIT levels and ovulatory PCOS patients had the highest serum sclerostin levels among the phenotypes. The results point out that patients with phenotypes A and B might develop more atherosclerosis than other phenotypes.

PCOS was accepted as a major independent risk factor for atherosclerotic cardiovascular disease ${ }^{(19)}$. Progestins (especially those with androgenic activity), oral contraceptives, and obesity are secondary causes of dyslipidemia ${ }^{(19)}$. PCOS patients have an increased risk for atherosclerosis because of the disease's nature and its treatment. Women with hyperandrogenic PCOS (phenotype A, B, and C) had a higher prevalence of cardiovascular disease compared with the nonhyperandrogenic PCOS phenotype (phenotype D) even after adjusting for age, 
smoking, BMI, and ethnic origin ${ }^{(20)}$. In a study by Rizzo et al. ${ }^{(21)}$, which compared ovulatory PCOS (phenotype C) with other phenotypes, ovulatory women with PCOS had milder forms of atherogenic dyslipidemia than women with anovulatory PCOS. Atherosclerosis risk was evaluated in this study by CIMT measurements in different PCOS phenotypes. In a study of young and normal-weight PCOS patients ${ }^{(22)}$, mean CIMT was found significantly higher than that in controls $(0.746 \pm 0.106$, $0.608 \pm 0.105$, respectively). Yildir et al. ${ }^{(23)}$ reported the mean CIMT as $0.50 \pm 0.11$ in overweight PCOS patients, but the difference was not significant. In a study that evaluated cardiovascular disease risk by CIMT measurements in different PCOS phenotypes, ovulatory PCOS patients (phenotype C) had lower CIMT values than the other three phenotypes ${ }^{(16)}$. The authors attributed this to anovulation as having a major negative effect on cardiovascular risk. Unlike the previous studies in PCOS patients evaluating CIMT, we also analyzed CIMT values adjusted for BMI. Significant differences occurred in CIMT among phenotypes after adjusting for BMI, and we found the CIMT values were highest to the lowest as phenotypes A, B, C, and D, respectively. In all the phenotypes in our study group, the means of CIMT were lower than the atherosclerosis cutoff. Because of the young age of the patients, the metabolic dysfunction might require additional time to become clinically evident. Different mean CIMT values for PCOS patients than in previous studies might be attributed to the BMI-adjusted analysis in this study. Atherosclerosis risk was significantly associated with high LDL, total cholesterol levels, and $\mathrm{BMI}^{(16)}$. Our phenotype A and B patients had higher lipid parameters and BMI than the other phenotypes. These data imply that anovulatory patients with hyperandrogenism had more atherosclerosis and cardiovascular risk than others. The prevalence of metabolic abnormalities was lower in phenotype $\mathrm{D}^{(20)}$, so it might suggest that androgens play a significant role in increasing the risk of metabolic and cardiovascular diseases. Recent data suggest Wnt signaling occurs in early atherogenesis ${ }^{(24)}$. Sclerostin, a soluble inhibitor of the Wnt signaling pathway, was reported to have a close relation to atherosclerosis in patients with chronic diseases ${ }^{(13,25)}$. We researched the relation between PCOS and sclerostin first in the literature. We found that BMI-adjusted serum sclerostin levels were significantly higher in women with PCOS than in healthy women. Sclerostin levels higher than $6.297 \mathrm{ng} / \mathrm{mL}$ could predict PCOS with a 56\% sensitivity. In the phenotype comparison, ovulatory PCOS patients (phenotype C) had the highest BMI-adjusted serum sclerostin levels following nonhyperandrogenic PCOS patients (phenotype D), and the lowest sclerostin levels were in the classic PCOS patients (phenotype B). We could not find a correlation between sclerostin and CIMT levels. This result could be related to CIMT values significantly higher in our PCOS patients than controls, although they were not as high as the atherosclerosis cut-off $(0.9 \mathrm{~mm})$. If we had an older and overweight/obese study population, atherosclerosis could be more significant in patients to show more clearly the relation between sclerostin and PCOS patients.

Atherosclerosis risk was significantly associated with the lipid profile and BMI. In the current study, sclerostin showed a weak positive correlation with total cholesterol and a weak negative correlation with HDL. Excess androgen appears to regulate metabolic and cardiovascular changes as an independent parameter ${ }^{(16)}$. While we have compared the parameters between PCOS patients with and without biochemical hyperandrogenism, we found the mean CIMT and sclerostin levels higher in the hyperandrogenic group. However, the two groups were found to be statistically similar.

We found significantly lower FSH and higher LH levels in patients with full and non-hyperandrogenic PCOS than in the control group, but the difference was not statistically significant between phenotypes. In the lipid parameters' comparison, the phenotypes A and B had the highest total cholesterol and LDL levels in PCOS patients. In contrast, the ovulatory PCOS (phenotype C) group had the lowest total cholesterol and LDL levels. In the literature, controversial data exist about the lipid profile of PCOS phenotypes. Daan et al. ${ }^{(20)}$ showed that in hyperandrogenic PCOS women, lipid profiles were significantly more disturbed, and metabolic syndrome was more prevalent than non-hyperandrogenic PCOS women. In contrast, some studies reported no difference existed in the cholesterol profile between PCOS phenotypes ${ }^{(3)}$. Dilbaz et al. ${ }^{(16)}$ reported that phenotype $C$ had the lowest mean LDL, total cholesterol levels, and BMI was similar to our results. Dyslipidemia is generally related to hyperandrogenism and obesity. Thus, phenotypes A and B had higher BMI levels and higher total testosterone levels. Phenotype C had lower BMI levels and lower total testosterone levels than other phenotypes had, and this could have contributed to the lipid profile.

PCOS is a metabolic disorder associated with IR. Insulin and HOMA-IR levels were higher in PCOS patients than in controls, but IR was not statistically significant among groups. Ozay et al. ${ }^{(26)}$ reported that HOMA-IR values had the same distribution among the four PCOS phenotypes with similar BMI values to ours. IR was compared in overweight PCOS patients with different phenotypes and was higher in phenotypes B and D than in other phenotypes ${ }^{(27)}$. Our results might be because our study was conducted on normal-weight PCOS patients.

\section{Study Limitations}

Our study has some strengths and limitations. To the best of our knowledge, this is the first published study that investigates the relationship between sclerostin and atherosclerosis in PCOS patients. PCOS consists of a broad spectrum of patients with heterogenic characteristics. This study tried to present the heterogeneity of phenotypes and demonstrate the atherosclerosis risk among groups. Atherosclerosis was evaluated using radiological and biochemical techniques. The 
limitations of this study include the young age and low BMI of the participants, the small sample size, and the lack of enough data on individual atherosclerosis risk factors.

\section{Conclusion}

The different PCOS phenotypes present similarities in the same group and vary regarding endocrine and metabolic parameters. It is essential to identify the risk groups to design a screening and follow-up program for them. We conclude that atherosclerosis risk was higher in PCOS patients with phenotypes A and B. Screening these patients closely may alter and modify the risk factors for future cardiovascular disease. Although sclerostin was higher in PCOS patients, more studies are required to define the association of sclerostin and atherosclerosis in different PCOS phenotypes.

\section{Ethics}

Ethics Committee Approval: This prospective case-control study was conducted from June 2019 to July 2020 at a tertiary hospital with approval from the local institutional review board (reg. no. 2019/184).

Informed Consent: All patients gave written informed consent after they were informed about the study protocol and aim.

Peer-review: Externally and internally peer-reviewed.

\section{Authorship Contributions}

Concept: F.N.İ.C., Design: F.N.İ.C., Data Collection or Processing: A.A., A.K., Analysis or Interpretation: Ü.C., E.Ç., Literature Search: O.G., Writing: F.N.İ.Ç.

Conflict of Interest: No conflict of interest was declared by the authors.

Financial Disclosure: The authors declared that this study received no financial support.

\section{References}

1. Bozdag G, Mumusoglu S, Zengin D, Karabulut E, Yildiz BO. The prevalence and phenotypic features of polycystic ovary syndrome: a systematic review and meta-analysis. Human Reprod 2016;31:284155.

2. Group REASPCW. Revised 2003 consensus on diagnostic criteria and long-term health risks related to polycystic ovary syndrome (PCOS). Hum Reprod 2004;19:41-7.

3. Lizneva D, Suturina L, Walker W, Brakta S, Gavrilova-Jordan L, Azziz R. Criteria, prevalence, and phenotypes of polycystic ovary syndrome. Fertil Steril 2016;106:6-15.

4. Dewailly D, Catteau-Jonard S, Reyss A-C, Leroy M, Pigny P. Oligoanovulation with polycystic ovaries but not overt hyperandrogenism. J Clin Endocrinol Metab 2006;91:3922-7.

5. Kim JJ, Hwang KR, Choi YM, Moon SY, Chae SJ, Park CW, et al. Complete phenotypic and metabolic profiles of a large consecutive cohort of untreated Korean women with polycystic ovary syndrome. Fertil Steril 2014;101:1424-30

6. Goverde A, Van Koert A, Eijkemans M, Knauff E, Westerveld H Fauser B, et al. Indicators for metabolic disturbances in anovulatory women with polycystic ovary syndrome diagnosed according to the Rotterdam consensus criteria. Hum Reprod 2009;24:710-7.
7. Carmina E, Chu M, Longo R, Rini G, Lobo R. Phenotypic variation in hyperandrogenic women influences the findings of abnormal metabolic and cardiovascular risk parameters. J Clin Endocrinol Metab 2005;90:2545-9.

8. Christian RC, Dumesic DA, Behrenbeck T, Oberg AL, Sheedy $\mathrm{PF}$, Fitzpatrick LA. Prevalence and predictors of coronary artery calcification in women with polycystic ovary syndrome. J Clin Endocrinol Metab 2003;88:2562-8.

9. Paradisi G, Steinberg HO, Hempfling A, Cronin J, Hook G, Shepard MK, et al. Polycystic ovary syndrome is associated with endothelial dysfunction. Circulation 2001;103:1410-5.

10. van Bezooijen RL, ten Dijke P, Papapoulos SE, Löwik CW. SOST/sclerostin, an osteocyte-derived negative regulator of bone formation. Cytokine Growth Factor Rev 2005;16:319-27.

11. Mani A, Radhakrishnan J, Wang H, Mani A, Mani MA, NelsonWilliams C, et al. LRP6 mutation in a family with early coronary disease and metabolic risk factors. Science 2007;315:1278-82.

12. Sarzani R, Salvi F, Bordicchia M, Guerra F, Battistoni I, Pagliariccio $\mathrm{G}$, et al. Carotid artery atherosclerosis in hypertensive patients with a functional LDL receptor-related protein 6 gene variant. Nutr Metab Cardiovasc Dis 2011;21:150-6.

13. Shalash MAM, Rohoma KH, Kandil NS, Abdel Mohsen MA, Taha AAF. Serum sclerostin level and its relation to subclinical atherosclerosis in subjects with type 2 diabetes. J Diabetes Complications 2019;33:592-7.

14. Chen A, Sun Y, Cui J, Zhao B, Wang H, Chen X, et al. Associations of sclerostin with carotid artery atherosclerosis and all-cause mortality in Chinese patients undergoing maintenance hemodialysis. BMC Nephrol 2018;19:264.

15. Hatch R, Rosenfield RL, Kim MH, Tredway D. Hirsutism: implications, etiology, and management. Am J Obstet Gynecol. 1981;140:815-30.

16. Dilbaz B, Özkaya E, Cinar M, Cakir E, Dilbaz S. Cardiovascular disease risk characteristics of the main polycystic ovary syndrome phenotypes. Endocrine 2011;39:272-7.

17. Balen AH, Laven JS, Tan SL, Dewailly D. Ultrasound assessment of the polycystic ovary: international consensus definitions. Hum Reprod Update 2003;9:505-14.

18. Simova I, Katova T, Denchev S. Diagnostic accuracy of flow-mediated dilatation and intima-media thickness for the presence of significant coronary artery disease. J Am Soc Hypertens 2009;3:388-94.

19. Jellinger PS, Handelsman Y, Rosenblit PD, Bloomgarden ZT, Fonseca VA, Garber AJ, et al. American Association of Clinical Endocrinologists and American College of Endocrinology guidelines for management of dyslipidemia and prevention of cardiovascular disease. Endocr Pract 2017;23(Suppl 2):1-87.

20. Daan NM, Louwers YV, Koster MP, Eijkemans MJ, de Rijke YB, Lentjes EW, et al. Cardiovascular and metabolic profiles amongst different polycystic ovary syndrome phenotypes: who is really at risk? Fertil Steril 2014;102:1444-51.

21. Rizzo M, Berneis K, Hersberger M, Pepe I, Di Fede G, Rini GB, et al. Milder forms of atherogenic dyslipidemia in ovulatory versus anovulatory polycystic ovary syndrome phenotype. Hum Reprod 2009;24:2286-92.

22. Vural B, Caliskan E, Turkoz E, Kilic T, Demirci A. Evaluation of metabolic syndrome frequency and premature carotid atherosclerosis in young women with polycystic ovary syndrome. Hum Reprod 2005;20:2409-13. 
23. Yildir IC, Kutluturk F, Tasliyurt T, Yelken BM, Acu B, Beyhan M, et al. Insulin resistance and cardiovascular risk factors in women with PCOS who have normal glucose tolerance test. Gynecol Endocrinol 2013;29:148-51.

24. Tsaousi A, Mill C, George SJ. The Wnt pathways in vascular disease: lessons from vascular development. Curr Opin Lipidol 2011;22:350-7.

25. Kirkpantur A, Balci M, Turkvatan A, Afsar B. Independent association between serum sclerostin levels and carotid artery atherosclerosis in prevalent haemodialysis patients. Clin Kidney J 2015;8:737-43

26. Ozay AC, Ozay OE, Gulekli B. Comparison of anti-müllerian hormone (aMh) and hormonal assays for Phenotypic Classification of Polycystic ovary Syndrome. Ginekol Pol 2020;91:661-7.

27. Panidis D, Tziomalos K, Misichronis G, Papadakis E, Betsas G, Katsikis I, et al. Insulin resistance and endocrine characteristics of the different phenotypes of polycystic ovary syndrome: a prospective study. Hum Reprod 2012;27:541-9. 